\title{
Student Interaction with Content in Online and Hybrid Courses: Leading Horses to the Proverbial Water
}

\author{
Meg Murray, Jorge Pérez, Debra Geist, and Alison Hedrick \\ Kennesaw State University, Kennesaw, GA, USA
}

\author{
mcmurray@kennesaw.edu jperez@kennesaw.edu \\ dgeist1@kennesaw.edu ahedric1@kennesaw.edu
}

\begin{abstract}
Permutations of traditional and online learning are rapidly advancing along a blended continuum, prompting conjecture that learning and e-learning will soon be indistinguishable. As variations of blended learning evolve, educators worldwide must develop better understanding of how effective interaction with course content impacts engagement and learning. This study compares patterns of access to instructional content in online and hybrid courses offered at a regional university in the United States. Frequency counts and access rates were examined for course content in four categories: core materials, direct support, indirect support, and ancillary materials. Observed results were echoed in responses to a survey of students, who reported selectively accessing course content based upon perceived likelihood of positive impact on performance. Implications for course design are myriad.
\end{abstract}

Keywords: Interaction theory, student/content interaction, distance education, online learning, blended learning, instructional design

\section{Introduction}

Interaction that results in knowledge transfer is the basis of education - interactions between teacher and student, student and student, and student and content (Moore, 1989). In the traditional classroom, the primary mode of interaction was face-to-face dialogue between teacher and student (Anderson, 2003b). As mediums for online delivery of academic coursework expanded with the evolution of the Internet, the primacy of interaction modes shifted. Delivery of education has evolved into a continuum with traditional face-to-face classes at one end and asynchronous courses conducted wholly online at the other. Along the continuum are combinations of traditional and online delivery methods that are commonly referred to as blended or hybrid. One noted shift in interaction pattern dynamics is increased importance of student/content interaction in online courses (Bernard et al., 2009). As hybrid forms emerge and evolve, their effectiveness is explored and compared with modes at both ends of the delivery method continuum. How do students interact with content in online versus hybrid courses? Does interaction with content corre-

Material published as part of this publication, either on-line or in print, is copyrighted by the Informing Science Institute. Permission to make digital or paper copy of part or all of these works for personal or classroom use is granted without fee provided that the copies are not made or distributed for profit or commercial advantage AND that copies 1) bear this notice in full and 2) give the full citation on the first page. It is permissible to abstract these works so long as credit is given. To copy in all other cases or to republish or to post on a server or to redistribute to lists requires specific permission and payment of a fee. Contact Publisher@InformingScience.org to request redistribution permission. late to course performance? Does course delivery mode impact student perceptions of their interaction with course content? This exploratory study compares patterns of student interaction with online content in online and hybrid courses and discusses implications for course design. Understanding the nuances of student interaction with content is particularly critical in course delivery 
modes that emphasize student/content rather than student/teacher interaction.

\section{Review of the Literature}

Interaction has long been identified as a defining and critical component of the educational process (Anderson, 2003a). Interaction between teachers, students and content occurs in all forms of education. Across the spectrum of distance education formats, Moore (1989) identified three modes of interaction that must be present: student/teacher, student/student, and student/content. Student/teacher interaction can take the form of face-to-face exchange between teacher and learner, as well as both synchronous and asynchronous digital communication in online or blended settings. Student/student interaction includes communication among classmates for the purpose of completing a course related activity and informal discourse about class subject matter. Student/content interaction refers to student engagement with course resources. Moore defined student/content interaction to be "the process of intellectually interacting with the content that results in changes in the learner's understanding, the learner's perspective, or the cognitive structures of the learner's mind" (p. 2). To Moore, student/content interaction defines education, for without it, education cannot occur.

Interactions of all types enhance the learning process and can be appropriate and effective in all educational venues. However, different kinds of interactions are appositive for different types of course delivery formats. Figure 1 is a model of the delivery mode continuum, from face-to-face to online learning, with blended/hybrid modes in between. Overlaid on the model are the three types of interaction: student/student, student/teacher, and student/content. It can be argued that each type of interaction mode is present in any educational setting. However, the dark shading in each type of interaction indicates the best fit between the interaction and a given delivery mode. For example, student/teacher interaction is dominant in traditional face-to-face classrooms while stu$\mathrm{dent} /$ content interaction is dominant in asynchronous online courses. Student/student interaction is not typically dominant in any course but does occur across the course format spectrum. The model reflects current research on interaction. Miyazoe and Anderson (2010) found that students place a higher value on interaction with teachers in face-to-face courses and on interaction with content in online courses; however, preference is distributed equally among types of interaction in blended learning environments.

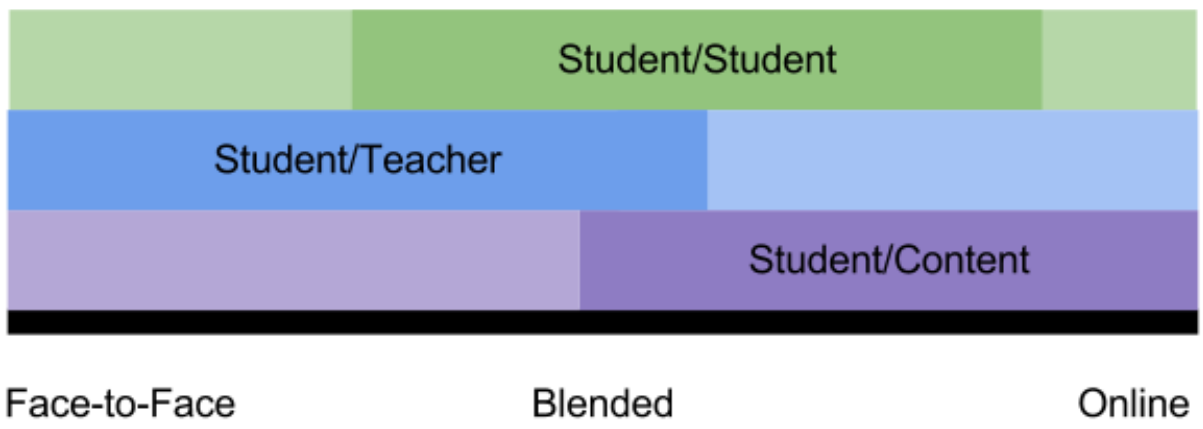

Figure 1. Delivery Mode Continuum and Interaction Type

One can envision in the model points of equilibrium where optimal combinations of the three interaction types are achieved for any course delivery format along the continuum. Research indicates that once the optimal mix has been established, increasing another type of interaction would yield diminishing returns, a phenomenon Anderson (2003a) referred to as the "Interaction Equivalency Theorem." Anderson (2003a) theorizes that "deep and meaningful formal learning is supported as long as one of the three forms of interaction (student/teacher, student/student, student/content) is at a high level" and that "the other two may be offered at minimal levels or even 
eliminated, without degrading the educational experience" (p. 3). Studies have supported the supposition that one kind of interaction can be more heavily weighted without expense to student learning gains (Miyazoe \& Anderson, 2010). The implications are that courses can be designed to heavily emphasize one type of interaction with minimal loss in educational effectiveness. Further, as institutions of higher education continue to expand distance learning offerings, more focus will be placed on student/content interaction. As Anderson (2003a) notes, there is pressure to transform student/teacher and student/student interactions into enhanced forms of student/content interaction.

Much has been written about each of the three modes of interaction -- student/teacher, student/student, and student/content -- and research has shown that each mode has a positive impact on student achievement (Bernard et al., 2009). However, studies of student/content interaction have primarily investigated the education impact that results after student engagement with a content-based educational resource. In other words, these studies only look at those situations where students have actively interacted with course content. They do not attempt to assess whether or not a student will engage with a course resource if given a choice; without access, there is no interaction. Identifying which resources students access is of particular interest in hybrid and online courses, wherein students independently decide which materials to access.

Since hybrid or blended modes seek to maximize the best elements of online and face-to-face learning (O'Brien, Hartshorne, Beattie, \& Jordan, 2011), considerable research has been conducted to compare online and blended learning. Overbaugh and Nikel (2011) conclude in one such study that students in both delivery modes were satisfied with the course and had equally high degrees of perceived learning. Another study found that student satisfaction in both online and hybrid course formats depends upon course content, student-teacher communications, the use of effective learning tools, and the instructor (Estelami, 2012).

While research indicates that student satisfaction with online learning is high, studies also indicate that retention rates are lower in online courses. One study that tracked students in online, hybrid and face-to-face courses for nearly five years found higher fail and withdrawal rates in online courses. On the other hand, students in hybrid courses were as likely to complete the course as those enrolled in face-to-face courses (Xu \& Smith Jaggars, 2011).

Dziuban and Moskal (2011) found, based upon end-of-course evaluation instruments, that student responses are not impacted by whether the course is delivered in an online, blended, or face-toface format. One interpretation is that students are becoming agnostic with regard to the delivery mode of courses in which they enroll. However, the same cannot be said of course developers and educators, who must design with modal idiosyncrasies in mind. Effective online and hybrid courses are dependent upon effective instructional designs that meet pedagogical needs. Frameworks, models, and taxonomies exist that can aid in the design of successful online and hybrid courses. For example, the Instructional Design for Online Learning (IDOL) model (Siragusa, Dixon, \& Dixon, 2007) prescribes approaches to instructional analysis, design, delivery, and evaluation of online courses. The model comprises elements such as established instructional design models, adequate content, a well-defined course infrastructure, use of online learning management systems, opportunities for robust feedback, and a course evaluation process.

Osguthorpe and Graham (2003, as cited in Tabor, 2007) recommend designing blended courses around six foundational goals: pedagogical richness, access to knowledge, social interaction, personal agency, cost effectiveness, and ease of revision. Hirumi (2011) recommends a five-step process for designing and sequencing e-learning interactions: a grounded instructional strategy based on desired learning outcomes and epistemological beliefs, an operational strategy that describes how each event will be applied during instruction, defined interactions to facilitate each 
event, tools to facilitate each event based on the nature of the interaction, and analysis of elearning interactions to enable revision as necessary.

In order for online or blended delivery of instruction to be successful, effective student engagement must be present (Gradel \& Edson, 2011). An efficacious online course must be a safe and vibrant virtual community. Instructors can create an engaged community by managing the relationship between technology and pedagogy, specifically with regard to course design, social presence, specially tailored assignments, learner expectations, objectives, and facilitation of sustained interaction with course material, fellow learners, and the instructor (Hege, 2011).

Both online and blended formats rely heavily on learner-based, cognitive learning styles where content is highly intertwined with collaborative learning. Tabor (2007) acknowledges the desire students have for more control over their learning environment, along with greater flexibility, but concludes that not all students possess the time management skills or motivational levels required for success in the online and hybrid formats. Placing the bulk of the learning in the hands of the students mandates tighter constraints on course content and format. Content delivered in an online course needs to be complete, relevant, and accurate and must include all the information necessary for students to successfully complete course requirements (Siragusa et. al., 2007). Siragusa et. al. (2007) outlined these resources to include detailed content, learning activities, assignment requirements and supporting materials.

Brown and Voltz (2005) maintain that "educational materials that have been effectively designed will facilitate the achievement of desired learning outcomes for students" (p.1.). The authors cite six design elements that should be present in the collection of resource materials provided to students in an online course. These elements mandate that learning resources include an activity or task that students must perform, a scenario or story that motivates a student to perform, opportunities for feedback, an appropriate delivery medium, consideration of the context of the learning environment, and attention to the influence each resource will have on student learning. Applying these six design elements generates instructional materials that contribute to the totality of the learning experience.

In most online and hybrid courses, students have access to a vast array of instructional materials. In a previous study, we found that students with the highest access rates are also the highest achievers (Murray, Pérez, Geist, \& Hedrick, 2012). These findings parallel what other researchers have found. Crampton, Ragusa, and Cavanagh (2012) observed that students who accessed the most content in terms of diversity and percentage of available resources achieved a higher grade. However, research has also shown that students prioritize the resources they access. Stewart, Stott, and Nuttall (2011) found that students accessed archived resources on-demand to help with assignments, not on a weekly basis to supplement lectures. On a similar premise, others found that students tend to access only materials that are directly tied to earning a grade (Murray et al., 2012). Tabor (2007) received student feedback suggesting that online topics would have merited additional study time if quizzes had been associated with them.

The evolution of Learning Management Systems (LMS) has made it easy to incorporate and disseminate a vast array of learning resources. Unfortunately, this abundance and variety of content does not always benefit students. Some online courses suffer because the sheer quantity of educational resources provided to the student does not align with course learning objectives (Koszalka $\&$ Ganesan, 2004). This is often due to the fact that course developers include extra options and resources simply because they can. To help prevent this from happening, Koszalka and Ganesan (2004) developed an instructional design taxonomy to help course developers strategically align LMS features with the teaching and learning goals of the course. The underlying principle of the taxonomy stipulates that course developers think strategically when designing the course to ensure that materials and features provided map directly to supporting course learning outcomes. 
This study that investigates student interaction with course content in online and hybrid environments poses the following questions:

1. What are the patterns of student access to online course content, and what types of materials do most students access?

2. Is there a difference in patterns of student access to online course content based on course delivery format (online versus hybrid)?

3. Is there a correlation between patterns of student access to online course content and course success as measured by course grades regardless of course delivery format (online versus hybrid)?

4. Are student perceptions of their patterns of access to online course content consistent regardless of course delivery format (online versus hybrid)?

5. Are the reasons students give for not accessing online course content different depending upon course delivery format (online versus hybrid)?

\section{Methodology}

The research methodology employed included tabulation of frequency counts of student access to course materials, access rate calculations, and statistical comparison between access patterns of students enrolled in online sections and hybrid sections of a digital literacy course. Offered at a regional university in the United States, the course is open to all students at the institution. Over 400 students from myriad degree programs enroll in the popular course each semester. This study looked at students enrolled in eight sections of the course offered in the spring and fall semesters of the 2011/2012 academic year. To minimize extraneous variability, all sections chosen for the study were taught by the same faculty member. Four sections studied were offered as hybrid courses and four sections were offered wholly online via asynchronous delivery and interaction. Hybrid course sections were blended in that half of the course was offered face-to-face and half of the course was offered online. Students met in a physical classroom once a week for 75 minutes, whereas a traditional face-to-face class meets twice a week for a total of 150 minutes per week. During the 16-week-long fall 2011 semester, 56 students completed the online sections with 44 receiving passing grades and 51 completed the hybrid sections with 44 receiving passing grades. During the spring 2012 semester, 58 students completed the online sections with 53 receiving passing grades and 63 completed the hybrid sections with 60 receiving passing grades. Students who did not successfully complete the course (in this study a grade of 60 or above on a scale of 0-100 is considered passing) are not included in this study. Table 1 shows enrollment data for students who successfully completed the course. Table 2 depicts the demographic distribution of these students. The majority of students were female, upper-class students of traditional college age.

Table 1: Student Enrollment Data for Students Successfully Completing the Course

\begin{tabular}{|l|r|r|}
\hline & Online & \multicolumn{1}{c|}{ Hybrid } \\
\hline Fall Semester & 44 & 44 \\
\hline Spring Semester & 53 & 60 \\
\hline \multicolumn{2}{|c|}{ Total } & 97 \\
\hline * Represents only students who completed the course \\
\hline \hline
\end{tabular}


Table 2: Student Demographic Data for Students Successfully Completing the Course

\begin{tabular}{|l|l|r|r|l|r|r|}
\hline & \multicolumn{3}{|c|}{ Online } & \multicolumn{3}{c|}{ Hybrid } \\
\hline Gender & & Count & Percent & & Count & Percent \\
\hline & Male & 30 & $30.9 \%$ & Male & 36 & $34.6 \%$ \\
\hline & Female & 67 & $69.1 \%$ & Female & 68 & $65.4 \%$ \\
\hline Age & & Count & Percent & & Count & Percent \\
\hline & $18-23$ & 49 & $50.5 \%$ & $18-23$ & 69 & $66.3 \%$ \\
\hline & $24-29$ & 24 & $24.7 \%$ & $24-29$ & 20 & $19.2 \%$ \\
\hline & over 30 & 24 & $24.7 \%$ & over 30 & 15 & $14.4 \%$ \\
\hline & Flass Standing & Count & Percent & & Count & Percent \\
\hline & 2 & $2.1 \%$ & Freshman & 1 & $1.0 \%$ \\
\hline & Sophomore & 10 & $10.3 \%$ & Sophomore & 13 & $12.5 \%$ \\
\hline & Junior & 35 & $36.1 \%$ & Junior & 37 & $35.6 \%$ \\
\hline & Senior & 50 & $51.5 \%$ & Senior & 53 & $51.0 \%$ \\
\hline \hline
\end{tabular}

\section{Course Content}

The organization of the hybrid and online courses was similar, as both featured weekly modules consisting of activities, assignments, and assessments. The activities section directed students to associated readings in the required electronic textbook as well as to additional instructional materials including links to online tutorials and instructional videos, related materials on the Web, and other instructor-prepared documents. Students in hybrid sections attended class once a week; students in the online sections were provided with online lecture presentations. Each week, students produced an assignment deliverable and completed an online quiz. In addition to assignments and quizzes, assessments in the course included two examinations: a midterm and a final.

The online version of the course passed a university-required certification before it could be offered to students. The university subscribes to Quality Matters (company website is available at http://www.qmprogram.org ), a peer-review process that applies a standardized rubric to evaluate 40 standards of quality shown to positively influence student learning (Legon \& Runyon, 2007). These standards of quality include course learning objectives, student assessment and measurement, instructional materials, course overview and introductions, learner interaction and engagement, course technology, learner support, and course accessibility. The course met all Quality Matters standards receiving high commendation for those areas related to instructional materials and course organization.

Most materials provided to students enrolled in online sections were also provided to students enrolled in hybrid sections. However, materials specific to course delivery format, such as technology guides for specialized software, were made available only to students in online sections. Moreover, instructor-developed lecture presentations were provided only to students in online sections. Only 74 resources that were common to all sections of the course are included for evaluation in this study. Course materials were posted within the university-standard learning management system accessible via the Web. This study analyzes student access patterns to those materials. It should be noted that access to the e-textbook and a course-required computer-basedtraining program were not tallied. These resources were bundled together as part of a course packet that students who enrolled in the course were required to access as part of an online registration process.

To facilitate evaluation of access, course resources were organized into four categories: core materials, direct support, indirect support, and ancillary materials. Core material included documents and resources provided to help students with course logistics, course navigation, and use of course technologies. Direct support resources provided guidance or instructional support neces- 
sary to complete course assignments and assessments. Indirect support included resources that augmented information provided in the text and helped students achieve a high level of success in meeting learning outcomes for a particular module. Ancillary materials provided students with additional resources to enhance learning and deepen understanding of topics presented.

Study data was collected via the course learning management system, which tracked individual student access to all available resources. For the purposes of this study, access to a resource represented a student opening the resource in the LMS. The number of times a resource was viewed was not tracked, nor was the time a student spent reviewing a resource. This approach was adopted in part because students could download materials to a local computer, where access to resources could not be tracked by the LMS.

Simple statistics were used to describe the data. Access rate is reported as the percentage of students who accessed a resource or collection of resources. Because of the nature of the data, the nonparametric Mann-Whitney test was used to compare resource access rates between online and hybrid students. With the lower number of resources, the U score was used for the core materials category, whereas a p-value was used for the three other categories. Descriptive statistics were also used to report findings of student perceptions of resource access.

\section{Findings}

Frequency counts and access rates were analyzed to discern patterns of student access to course content in four categories: core materials, direct support, indirect support, and ancillary materials.

\section{Core Materials}

The core materials category contained five resource items, including the syllabus, schedule of topics, course netiquette, and instructions for enrolling in the electronic textbook and computerbased training program. The majority of students in both online and hybrid sections of the course accessed most of these resources. For example, more than $95 \%$ of the students accessed the syllabus, course schedule, and the instructions for enrolling in the computer based training program. One exception was student access to the course netiquette statement, which defines class rules for online student behavior. Considerably fewer students in both groups opened this resource. While the hybrid student access rate was slightly lower, no significant difference between the groups was evident (Mann-Whitney U score of 15; not significant at the .05 level). Access rates for the category of core material are shown in Table 3.

Table 3. Student Access Rates for Core Material Resources

\begin{tabular}{|c|c|c|c|c|}
\hline \multirow[b]{2}{*}{ Resource Name } & \multicolumn{2}{|c|}{$\begin{array}{l}\text { Hybrid } \\
\text { N=104 }\end{array}$} & \multicolumn{2}{|c|}{$\begin{array}{l}\text { Online } \\
\mathrm{N}=97\end{array}$} \\
\hline & $\begin{array}{c}\text { \# of Stu- } \\
\text { dents }\end{array}$ & $\begin{array}{l}\text { Access } \\
\text { Rate }\end{array}$ & $\begin{array}{c}\text { \# of Stu- } \\
\text { dents }\end{array}$ & $\begin{array}{l}\text { Access } \\
\text { Rate }\end{array}$ \\
\hline Course Syllabus & 103 & 0.99 & 95 & 0.98 \\
\hline Course Schedule of Topics & 101 & 0.97 & 94 & 0.97 \\
\hline Course Netiquette & 28 & 0.27 & 61 & 0.63 \\
\hline Instructions for e-Textbook Registration & 74 & 0.71 & 80 & 0.82 \\
\hline Instructions for CBT Registration & 99 & 0.95 & 97 & 1.00 \\
\hline Access Rate for All Resources in this Category & & 0.78 & & 0.88 \\
\hline
\end{tabular}

*Mann-Whitney U score = 15; not significant 


\section{Direct Support}

Direct support resources consisted of nineteen offerings, including module guides and assignment instructions. Module guides outlined learning objectives for each topic area and specified weekly activities, assignment, and assessments to be completed by students. In the online sections, a majority of students accessed all of the resources in this category. Access rates for students enrolled in the hybrid sections were significantly lower ( $p=.004242$; significance level $>.01)$. Data for direct support access rates is shown in Table 4. Even though access rates were different between the two groups, the pattern for which resources were accessed and when they were accessed is similar. It appears that fewer students accessed the module guides as the semester progressed. Figure 2 depicts module guide access.

Table 4. Student Access Rates for Direct Material Resources

\begin{tabular}{|c|c|c|c|c|}
\hline \multirow[b]{2}{*}{ Resource Name } & \multicolumn{2}{|c|}{$\begin{array}{l}\text { Hybrid } \\
\text { N=104 }\end{array}$} & \multicolumn{2}{|c|}{$\begin{array}{c}\text { Online } \\
\mathbf{N}=97\end{array}$} \\
\hline & $\begin{array}{c}\text { \# of Stu- } \\
\text { dents }\end{array}$ & $\begin{array}{l}\text { Access } \\
\text { Rate }\end{array}$ & $\begin{array}{c}\text { \# of Stu- } \\
\text { dents }\end{array}$ & $\begin{array}{l}\text { Access } \\
\text { Rate }\end{array}$ \\
\hline Module 01 Guide & 85 & 0.82 & 78 & 0.80 \\
\hline Module 02 Guide & 76 & 0.73 & 86 & 0.89 \\
\hline Module 03 Guide & 70 & 0.67 & 86 & 0.89 \\
\hline Module 04 Guide & 70 & 0.67 & 78 & 0.80 \\
\hline Module 05 Guide & 79 & 0.76 & 85 & 0.88 \\
\hline Module 06 Guide & 79 & 0.76 & 86 & 0.89 \\
\hline Module 07 Guide & 65 & 0.63 & 71 & 0.73 \\
\hline Module 08 Guide & 45 & 0.43 & 63 & 0.65 \\
\hline Module 09 Guide & 49 & 0.47 & 62 & 0.64 \\
\hline Module 10 Guide & 63 & 0.61 & 71 & 0.73 \\
\hline Module 11 Guide & 47 & 0.45 & 65 & 0.67 \\
\hline Module 12 Guide & 53 & 0.51 & 57 & 0.59 \\
\hline Module 13 Guide & 47 & 0.45 & 65 & 0.67 \\
\hline Module 14 Guide & 48 & 0.46 & 66 & 0.68 \\
\hline Module 15 Guide & 47 & 0.45 & 76 & 0.78 \\
\hline Module 16 Guide & 38 & 0.37 & 66 & 0.68 \\
\hline Assignment Instructions Mobile Devices & 101 & 0.97 & 94 & 0.97 \\
\hline Assignment Instructions Information Security & 95 & 0.91 & 94 & 0.97 \\
\hline Instructions for Uploading Files to a Web Server & 56 & 0.54 & 76 & 0.78 \\
\hline Access Rate for All Resources in this Category & & 0.61 & & 0.77 \\
\hline
\end{tabular}

${ }^{*}$ p-value $=.004242 ;$ significance level $>.01$ 


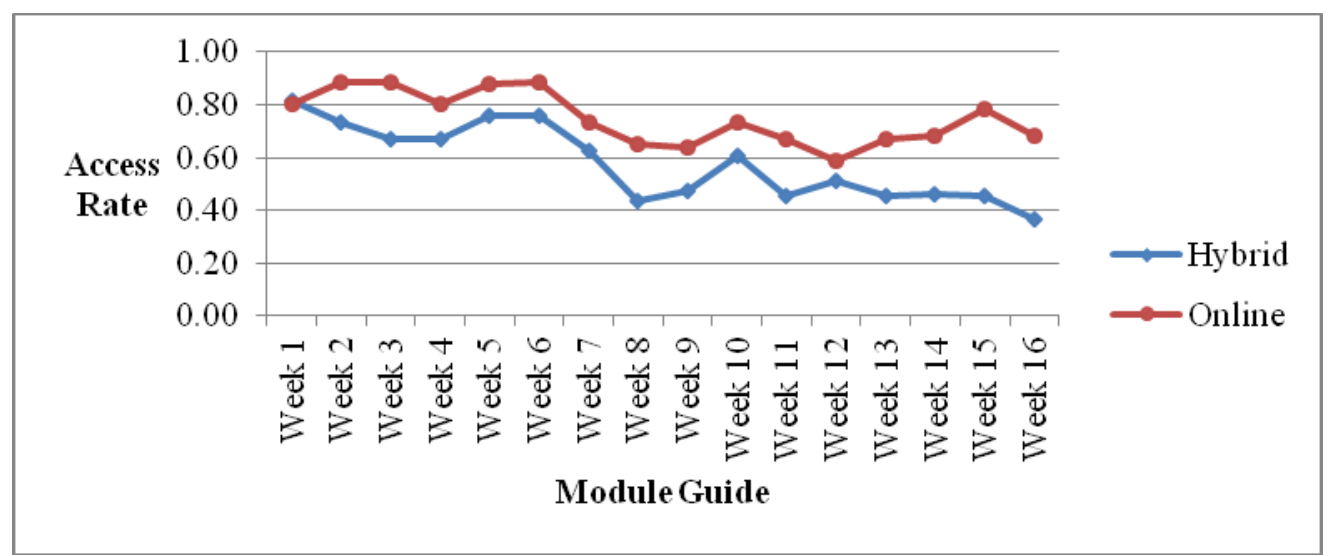

Figure 2. Module Guide Access Hybrid versus Online

\section{Indirect Support}

Sixteen indirect support resources provided students with extra instructional materials such as tutorials designed to enhance understanding and improve performance on assignments and assessments. As with direct support materials, the access rate was higher for online students, although the difference was only marginally significant ( $p=.023124$; significance level $>.05)$. However, for both groups the overall access rate for these materials was less than $50 \%$. This also holds true with regard to access to most of the individual materials. In the hybrid group, only four resources had access rates greater than $50 \%$. In the online group, six resources were accessed by a majority of the students. One of these had an access rate of $90 \%$, possibly indicating that online students perceived that this information was needed to complete an assignment. Data for indirect support resource materials access is shown in Table 5. Even though access rates differed somewhat between hybrid and online students, access patterns for individual resources were similar. Figure 3 depicts individual resource access. Resource materials are ordered chronologically, in the order in which they were made available to students.

Table 5. Student Access Rates for Indirect Material Resources

\begin{tabular}{|c|c|c|c|c|}
\hline \multirow[b]{2}{*}{ Resource Name } & \multicolumn{2}{|c|}{$\begin{array}{c}\text { Hybrid } \\
\mathrm{N}=104\end{array}$} & \multicolumn{2}{|c|}{$\begin{array}{c}\text { Online } \\
\mathbf{N}=97\end{array}$} \\
\hline & $\begin{array}{c}\text { \# of Stu- } \\
\text { dents }\end{array}$ & $\begin{array}{l}\text { Access } \\
\text { Rate }\end{array}$ & $\begin{array}{c}\text { \# of Stu- } \\
\text { dents }\end{array}$ & $\begin{array}{c}\text { Access } \\
\text { Rate }\end{array}$ \\
\hline Notes on Binary Number System & 70 & 0.67 & 71 & 0.73 \\
\hline Notes on Boot Process & 34 & 0.33 & 65 & 0.67 \\
\hline Finding computer properties & 44 & 0.42 & 44 & 0.45 \\
\hline Notes on OS & 59 & 0.57 & 70 & 0.72 \\
\hline Manual for KSU Files.edu & 52 & 0.50 & 60 & 0.62 \\
\hline CBT Guide Training & 30 & 0.29 & 37 & 0.38 \\
\hline CBT Guide Projects & 14 & 0.13 & 30 & 0.31 \\
\hline CBT Guide Reports & 15 & 0.14 & 56 & 0.58 \\
\hline Notes on File Systems & 54 & 0.52 & 87 & 0.90 \\
\hline Notes on Creating Excel Function & 14 & 0.13 & 20 & 0.21 \\
\hline Notes on Creating Excel Formula & 13 & 0.13 & 16 & 0.16 \\
\hline Notes on Excel Absolute References & 11 & 0.11 & 15 & 0.15 \\
\hline Database Fundamentals $\{$ web link $\}$ & 18 & 0.17 & 35 & 0.36 \\
\hline Intute Virtual Training $\{$ web link $\}$ & 23 & 0.22 & 34 & 0.35 \\
\hline
\end{tabular}




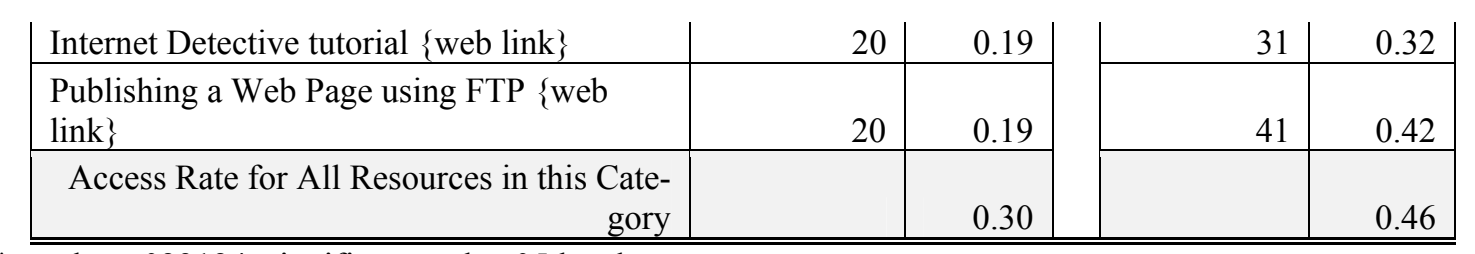

$* \mathrm{p}$-value $=.023124 ;$ significant at the .05 level

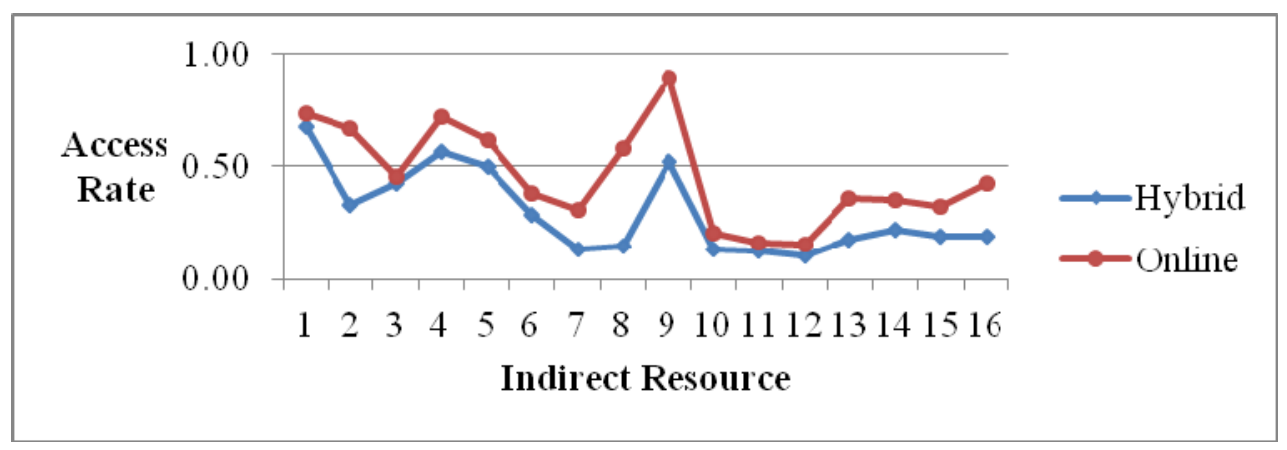

Figure 3. Indirect Resources Access Hybrid versus Online

\section{Ancillary Materials}

Ancillary materials to enhance learning and deepen understanding supplemented other available course resources. Videos that demonstrated a particular concept are an example of the thirty-two ancillary materials made available to students. Access rates to these materials were low for both groups (overall rate of $12 \%$ hybrid and $25 \%$ online). However, access rates were again higher for students in the online group than for students in the hybrid group. In fact, the difference between the two groups is highly significant $(p=.000502$; significance level $>.001)$. All ancillary materials were accessed by at least five different online students, while five ancillary resources were not accessed by any student enrolled in a hybrid section. Data for ancillary resource materials access is shown in Table 6. Patterns of resource access for hybrid and online students are shown in Figure 4. Again, even though there was a significant difference in access rates between the groups, access patterns to individual resources were similar and it appears that access rates decreased as the semester progressed. Resource materials are ordered chronologically, in the order in which they were made available to students.

Table 6. Student Access Rates for Ancillary Material Resources

\begin{tabular}{|c|c|c|c|c|}
\hline \multirow[b]{2}{*}{ Resource Name } & \multicolumn{2}{|c|}{$\begin{array}{l}\text { Hybrid } \\
N=104\end{array}$} & \multicolumn{2}{|c|}{$\begin{array}{c}\text { Online } \\
\mathbf{N}=97\end{array}$} \\
\hline & $\begin{array}{c}\# \text { of Stu- } \\
\text { dents }\end{array}$ & $\begin{array}{l}\text { Access } \\
\text { Rate }\end{array}$ & $\begin{array}{c}\text { \# of Stu- } \\
\text { dents }\end{array}$ & $\begin{array}{l}\text { Access } \\
\text { Rate }\end{array}$ \\
\hline Experiment with converting bits to bytes & 54 & 0.52 & 61 & 0.63 \\
\hline Four Basic Functions of a Computer $\{$ web link $\}$ & 49 & 0.47 & 62 & 0.64 \\
\hline Microprocessors $\{$ web link $\}$ & 2 & 0.02 & 19 & 0.20 \\
\hline How Computer Memory Works $\{$ web link $\}$ & 3 & 0.03 & 26 & 0.27 \\
\hline How does my Computer Think? \{web link $\}$ & 14 & 0.13 & 20 & 0.21 \\
\hline Managing and Maintaining Your Computer $\{$ web link $\}$ & 16 & 0.15 & 31 & 0.32 \\
\hline Understanding the Parts of your Computer $\{$ web link $\}$ & 14 & 0.13 & 23 & 0.24 \\
\hline How to Upgrade your Ram $\{$ web link $\}$ & 5 & 0.05 & 21 & 0.22 \\
\hline BIOS $\{$ web link $\}$ & 25 & 0.24 & 52 & 0.54 \\
\hline Disk Fragmentation $\{$ web link $\}$ & 9 & 0.09 & 23 & 0.24 \\
\hline OS Online Tutorial & 33 & 0.32 & 54 & 0.56 \\
\hline
\end{tabular}




\begin{tabular}{|c|c|c|c|c|}
\hline KSU ITS Training Booklets & 21 & 0.20 & 18 & 0.19 \\
\hline Excel 2010 Overview of Charts $\{$ web link $\}$ & 5 & 0.05 & 16 & 0.16 \\
\hline Excel 2010 How to Create Charts \{web link\} & 5 & 0.05 & 11 & 0.11 \\
\hline Excel 2010 Tutorial on Sparklines $\{$ web link\} & 3 & 0.03 & 11 & 0.11 \\
\hline Animated Database Tutorial $\{$ web link $\}$ & 14 & 0.13 & 43 & 0.44 \\
\hline Wireless Home Network \{web link\} & 16 & 0.15 & 11 & 0.11 \\
\hline Anatomy of a URL $\{$ web link $\}$ & 15 & 0.14 & 37 & 0.38 \\
\hline More URL anatomy $\{$ web link $\}$ & 10 & 0.10 & 26 & 0.27 \\
\hline Web Design Basics What's New in & 13 & 0.13 & 40 & 0.41 \\
\hline Dept of Homeland Security $\{$ web link $\}$ & 23 & 0.22 & 32 & 0.33 \\
\hline Usability of Passwords \{web link $\}$ & 14 & 0.13 & 23 & 0.24 \\
\hline How Secure Is Your Password \{web link\} & 26 & 0.25 & 33 & 0.34 \\
\hline Digitizing Images $\{$ web link $\}$ & 1 & 0.01 & 12 & 0.12 \\
\hline Searching Images on Web $\{$ web link $\}$ & 1 & 0.01 & 5 & 0.05 \\
\hline Raster Graphics \{web link\} & 0 & 0.00 & 11 & 0.11 \\
\hline Online Image Editing Program $\{$ web link $\}$ & 5 & 0.05 & 12 & 0.12 \\
\hline Digitizing Audio $\{$ web link $\}$ & 1 & 0.01 & 10 & 0.10 \\
\hline Finding audio resources on Web $\{$ web link $\}$ & 0 & 0.00 & 6 & 0.06 \\
\hline Online Audio Editing Program $\{$ web link $\}$ & 0 & 0.00 & 6 & 0.06 \\
\hline Digitization - What else is left? $\{$ web link $\}$ & 0 & 0.00 & 7 & 0.07 \\
\hline Can senses be digitized $\{$ web link $\}$ & 0 & 0.00 & 5 & 0.05 \\
\hline Access Rate for All Resources in this Cate & & 0.12 & & 0.25 \\
\hline
\end{tabular}

*p-value $=.000502$; significance level $>.001$

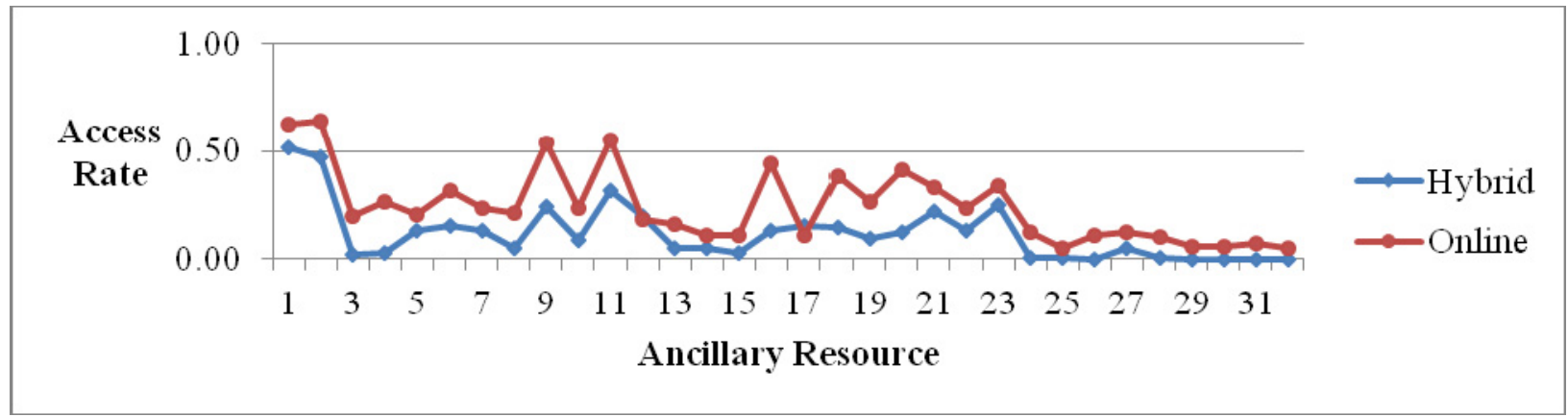

Figure 4. Ancillary Material Resource Access Hybrid versus Online

\section{Discussion}

\section{Student Success}

Course content is intended to facilitate and magnify student learning. In theory, a relationship between student interaction with content and student success can be hypothesized. That is, the more resources a student views, the higher their grade is likely to be on a specific component and thus in the course overall. Grades are used to measure student success. In this study, grades are presented categorically with A being the highest possible grade and D being the lowest grade. Students who did not pass the course are not included in the study. It should also be noted there was no significant difference between grades received by hybrid students and online students (U score of 15; not significant). The majority of students in both groups received high grades. Student grades for hybrid and online students are shown in Table 7. In addition, an overall access rate is presented. This rate simply divides a tally of all resources viewed by students receiving the associated grade divided by the number of possible views if all students had accessed all resources. The overall access rate was higher for the highest grade category, although this trend 
does not hold for the lowest grade category. The overall access rate does not take into consideration individual student characteristics. A plot of individual student access rates by grade received for both hybrid and online students is depicted in Figure 5. Individual student access rates were determined by dividing number of resources a student viewed by the total number of resources available. Individual differences are evident on the scatter plot; however, a trend is also apparent. Students receiving the highest grades had the highest access rates and students receiving the lowest grades had low access rates. While some students with low access rates still received high grades, no student with a low grade had a high access rate.

\begin{tabular}{|c|r|r|r|r|}
\hline \multicolumn{5}{|c|}{ Table 7. Student Grades by Category } \\
\hline & \multicolumn{2}{|c|}{ Hybrid } & \multicolumn{2}{c|}{ Online } \\
\hline Grade & $\begin{array}{c}\text { \# of } \\
\text { Students }\end{array}$ & $\begin{array}{c}\text { Overall } \\
\text { Access Rate }\end{array}$ & $\begin{array}{c}\text { \# of } \\
\text { Students }\end{array}$ & $\begin{array}{c}\text { Overall } \\
\text { Access Rate }\end{array}$ \\
\hline A & 53 & 0.4023 & 52 & 0.5724 \\
\hline B & 38 & 0.3337 & 22 & 0.4943 \\
\hline C & 8 & 0.2830 & 15 & 0.4935 \\
\hline D & 5 & 0.3583 & 8 & 0.4201 \\
\hline \hline
\end{tabular}
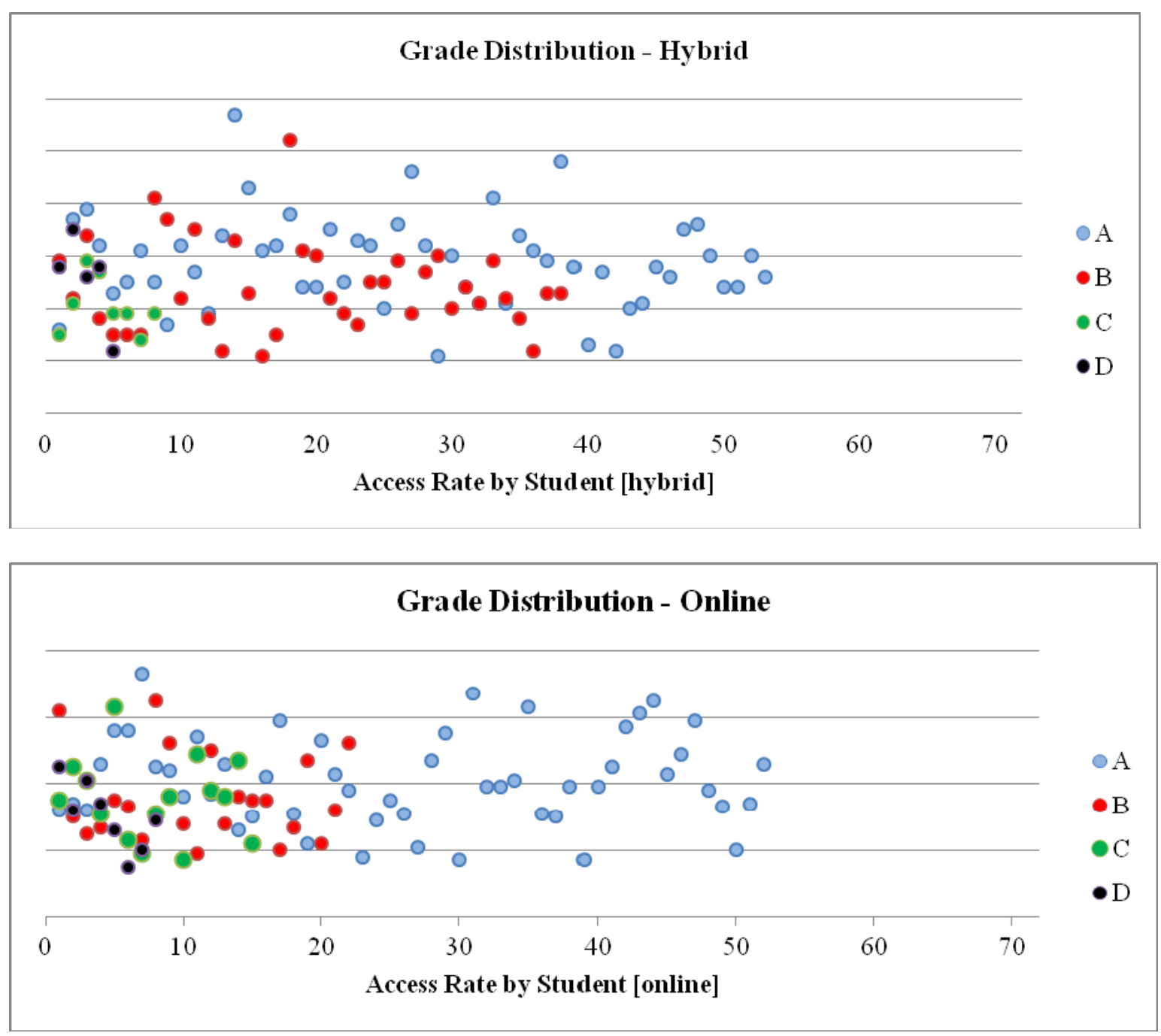

Figure 5. Individual Student Content Access Rate by Grade Received 


\section{Student Perceptions of Course Content Access Patterns}

Students were surveyed and asked to 1) report how often they accessed course materials and 2) provide their perceptions of why they do or do not access course materials. Ninety-five out of 104 students who completed the hybrid sections answered the survey. Seventy-three of the 97 students who completed the online section responded to the survey. In all content categories, online students reported a higher viewing rate than students in the hybrid sections. The majority of students in both online and hybrid sections reported viewing all or most of the core or direct materials. This is consistent with the findings from access data recorded by the learning management system. Fewer students from all sections of the course reported viewing ancillary materials whether they were documents or links to media sources; however, slightly more students reported viewing these materials than the access rate data supports. More online students reported accessing indirect materials than what was in actuality the case. In general, however, student self-reports of access patterns paralleled trends observed in data tracked by the LMS. Student response data is reported in Table 8.

Table 8. Reported Student Access to Course Content by Content Category

\begin{tabular}{|l|r|r|r|r|r|r|r|r|}
\hline \multicolumn{1}{|c|}{ Resource Category } & \multicolumn{2}{c|}{ all } & \multicolumn{2}{c|}{ most } & \multicolumn{2}{c|}{ Some } & \multicolumn{2}{c|}{ none } \\
\hline & Hybrid & Online & Hybrid & Online & Hybrid & Online & Hybrid & Online \\
\hline Core Materials & $31.9 \%$ & $47.2 \%$ & $27.2 \%$ & $25.0 \%$ & $25.5 \%$ & $19.4 \%$ & $14.9 \%$ & $8.3 \%$ \\
\hline Direct Materials & $34.8 \%$ & $57.7 \%$ & $33.7 \%$ & $25.4 \%$ & $23.9 \%$ & $16.9 \%$ & $7.6 \%$ & $0.0 \%$ \\
\hline Indirect Materials & $6.5 \%$ & $47.9 \%$ & $26.9 \%$ & $27.4 \%$ & $44.1 \%$ & $17.8 \%$ & $22.6 \%$ & $6.8 \%$ \\
\hline $\begin{array}{l}\text { Ancillary Materials - } \\
\text { documents }\end{array}$ & $8.5 \%$ & $19.2 \%$ & $38.3 \%$ & $37.0 \%$ & $43.6 \%$ & $37.0 \%$ & $9.6 \%$ & $6.8 \%$ \\
\hline $\begin{array}{l}\text { Ancillary Materials - } \\
\text { web links }\end{array}$ & $4.3 \%$ & $9.6 \%$ & $16.1 \%$ & $34.2 \%$ & $47.3 \%$ & $37.0 \%$ & $32.3 \%$ & $19.2 \%$ \\
\hline & & & & & & & & \\
\hline
\end{tabular}

The survey consisted of two sections to ascertain why students did or did not access course resources. The first section included open-ended questions. The second section provided a listing of four previously identified reasons and asked students to rank order them. Table 9 depicts student rankings, which were based on a weighted score using a scale of 1(lowest) to 5 (highest). While there was slight difference in the rank order between online and hybrid students, the difference was not statistically significant ( $\mathrm{U}=15$; not significant). The reason for not accessing materials that was ranked highest by both groups was that the resource was not necessary to complete graded assignments.

Table 9. Student Ranking of Reasons for Not Accessing Course Resources

\begin{tabular}{|l|r|r|}
\hline \multirow{2}{*}{ Did not think resources were necessary to complete graded assignments } & \multicolumn{2}{|c|}{ Weighted Score } \\
\cline { 2 - 3 } & Hybrid & Online \\
\hline Do not generally open resources not part of a graded assignment & 3.51 & 3.41 \\
\hline Did not have enough time & 3.38 & 3.16 \\
\hline Did not think the material had value & 3.22 & 3.20 \\
\hline Did not realize the resources were available & 2.49 & 2.42 \\
\hline & 2.16 & 2.23 \\
\hline
\end{tabular}

*Mann-Whitney U score $=15$; not significant

Time constraints were also given a high ranking. This was echoed in responses to open-ended survey questions, wherein time was frequently mentioned as a reason students do not access re- 
sources. Another reason often cited was that students did not access materials they perceived they did not need. Several students in hybrid sections indicated that they did not access many posted resources because they felt that the material had been covered in class. While many students cited that the resources were valuable, that value was relative. Students reported that they accessed materials if they did not have requisite knowledge, if they had difficulty with a particular topic, or if the information they were looking for was not easily found in the text or a Google search. One student summed it up by stating, "A good grade for the class is very important, but so is time. So unless the additional information provided assistance, I did not use it." When asked to provide additional information that would help identify why other students selectively access course resources, students again indicated that time was a factor and that materials may not be "relevant enough to help their grade." Others indicated a lack of effort on the part of their classmates, and a concern that some materials were simply posted as "added work." Students appear to be selective and strategic in the resources they access; as one student stated, "students probably only used resources on an as needed basis."

This study found that students access course resources with priority given to those resources students perceive have a direct impact on their grade. Resources categorized as core materials or direct materials had higher access rates than materials categorized as indirect or ancillary. Further, even though access rates for students enrolled in hybrid sections were consistently lower than those for students enrolled in online sections, access patterns were similar for both groups of students. The resources viewed by most students in hybrid course were the same resources viewed by most students in online sections. Similarities were also found between online students and hybrid students in terms of grades received and access patterns. Students with higher access rates earned higher grades and students with the lowest grades accessed fewer resources. Finally, student perceptions for why student do or do not access course resources was consistent across groups. Time and perceived value of the resource were the most cited reasons that impact a student's decision to access course material.

\section{Conclusion}

As the number of students taking online courses increases and blended learning opportunities grow, student interaction with course content will play a more central role in the teaching and learning process. Best practices for designing effective online and blended learning environments include the imperative to develop and effectively integrate high-quality instructional content. However, as this study demonstrates, simply making more resources available to students is not enough. Students are selective and intentional in their interaction with course content. Students give priority to course materials they perceive to be directly related to earning a good grade. Time constraints are reported as the primary reason that students selectively access course content. While students appreciate the availability of abundant course content, they employ strategies that they perceive will provide an optimal outcome. As one student noted, if it is important to access specific content, that resource must be mapped directly to earning points towards a grade. Similarly, another student reported reluctance to access content in the absence of a resulting penalty for not accessing the resource. The implications of these findings for designing e-learning environments are myriad.

Practical implications for the design of not only courses but also learning management systems flow from the findings of this study. In light of the observation that students tend to access only content that they perceive to be associated with achieving a good grade, learning management system developers could add features that allow instructors to track and give student's credit for access to critical course content. Moreover, scheduling rubrics could be designed to require course content to be accessed regularly throughout a span of time (i.e., three days during a week that a course module is being covered) instead of allowing students to procrastinate, accessing 
content and completing assignments and assessments only on the same day that everything is due to be completed.

Another implication of our findings for course designers is that content must be organized effectively and intuitively, following established instructional design principles. Extending this logic further, course designers should have in mind the goal of compelling students to access course content via interaction flow, structure, organization, and learning objectives. In other words, designers can and should leverage course design principles to impart value to course content above and beyond the achievement of a grade.

Our findings also indicate that non-critical, supplemental content is largely ignored by students. Perhaps one explanation is that in the age of information overload, students rely upon instructors to provide course content that is both relevant and useful. This is a particularly compelling finding given that at least one popular rubric used to certify the quality of online courses puts a positive spin on abundance of course content.

The research questions that were explored led to findings that were both intuitive and suggestive of the need for further investigation. Interaction theory, media richness, and informing science are but a few among myriad conceptual frameworks that might guide such explorations. For example, within the informing science paradigm, knowledge transfer occurs as informer, channel, and receiver interact in a complex environment (Cohen, 2009). Moreover, informing science theory posits that an individual's multifaceted information needs interact with task requirements in the milieu of informer, channel, and receiver -- dynamics that mirror any classroom setting or learning situation. As Cohen (2009) notes, "Important discoveries remain to be made regarding how such networks are impacted by other characteristics of the informing context, such as the underlying task/need driving the informing process and how informer/client characteristics impact the process and its evolution" (p. 11). Students tend to access content that they believe is linked to achieving a good grade in a course. Indeed, high access rates were found to be associated with high grades. Student self-reports of access to course resources align closely with access rates captured by the learning management system. As hybrid and online learning spread rapidly across the landscape of higher education, leading to greater emphasis on student/content interaction, the imperative of understanding interaction dynamics and nuances across the continuum is reinforced.

\section{References}

Anderson, T. (2003a). Getting the mix right again: An updated and theoretical rationale for interaction. International Review of Research in Open and Distance Learning, 4(2). Retrieved from http://www.irrodl.org/index.php/irrodl/article/view/149/230

Anderson, T. (2003b). Modes of interaction in distance education: Recent developments and research questions. In D. M. Moore (Ed.), Handbook of distance education (pp. 129-144). Mahwah, NJ: Erlbaum.

Bernard, R. M., Abrami, P. C., Borokhovski, E., Wade, C. A., Tamin, R. M., Surkes, M. A., \& Bethel, E. C. (2009). A meta-analysis of three types of interaction treatments in distance education. Review of Educational Research, 79(3), 1243-1289.

Brown, A., \& Voltz, B. (2005). Elements of effective e-Learning design. The International Review of Research in Open and Distance Learning, 6(1). Retrieved from http://www.irrodl.org/index.php/irrodl/article/view/217

Cohen, E. B. (2009). A philosophy of informing science. Informing Science: the International Journal of an Emerging Transdiscipline, 12, 1-15. Retrieved from http://www.inform.nu/Articles/Vol12/ISJv12p001-015Cohen399.pdf 
Crampton, A., Ragusa, A., \& Cavanagh, H. (2012). Cross-discipline investigation of the relationship between academic performance and online resource access by distance education students. Research in Learning Technology, 20.

Dziuban, C., \& Moskal, P. (2011). A course is a course is a course: Factor invariance in student evaluation of online, blended and face-to-face learning environments. Internet and Higher Education, 14, 236241.

Estelami, H. (2012,). An exploratory study of the drivers of student satisfaction and learning experience in hybrid-online and purely online marketing courses. Marketing Education Review, 22(2), 143-155.

Gradel, K., \& Edson, A. J. (2010-2011). Cooperative learning: Smart pedagogy and tools for online and hybrid courses. Journal of Educational Technology Systems, 39(2), 193-212.

Hege, B. A. (2011). The online theology classroom: Strategies for engaging a community of distance learners in a hybrid model of online education. Teaching Theology and Religion, 14(1), 13-20.

Hirumi, A. (2011). The design and sequencing of online and blended learning interactions: A framework for grounded design. The Canadian Learning Journal, 16(2), 21-25.

Koszalka, T. A., \& Ganesan, R. (2004). Designing online courses: A taxonomy to guide strategic use of features available in course management systems (CMS) in distance education. Distance Education, 25(2), 243-256.

Legon, R., \& Runyon, J. (2007). Research on the impact of the Quality Matters Course Review Process. Proceedings of the 23rd Annual Conference on Distance Teaching \& Learning. Madison, WI August $8-10,2007$. Retrieved from http://www.uwex.edu/disted/conference/Resource library/proceedings/07_5284.pdf

Miyazoe, T., \& Anderson, T. (2010). The interaction equivalency theorem. Journal of Interactive Online Learning, 9(2), 94-104.

Moore, M. (1989). Three types of interaction. The American Journal of Distance Education, 3(2), 1-7.

Murray, M., Pérez, J., Geist, D., \& Hedrick, A. (2012). Student interaction with online course content: Build it and they might come. Journal of Information Technology Education: Research, 11, 125-140.

O'Brien, C., Hartshorne, R., Beattie, J., \& Jordan, L. (2011). A comparison of large lecture, fully online, and hybrid sections of introduction to special education. Rural Special Education Quarterly, 30(4), 1931.

Overbaugh, R. C., \& Nickel, C. E. (2011). A comparison of student satisfaction and value of academic community between blended and online sections of a university-level educational foundations course. The Internet and Higher Education, 14(3), 164-174.

Siragusa, L., Dixon, K. C., \& Dixon, R. (2007). Designing quality e-learning environments in higher education. In ICT: Providing choices for learners and learning. Proceedings ascilite Singapore 2007. Available from http://www.ascilite.org.au/conferences/singapore07/procs/siragusa.pdf

Stewart, M., Stott, T., \& Nuttall, A. M. (2011). Student engagement patterns over the duration of level 1 and level 3 geography modules: Influences on student attendance, performance and use of online resources. Journal of Geography in Higher Education, 35(1), 47-65.

Tabor, S. W. (2007). Narrowing the distance. Implementing a hybrid learning model for information security management. The Quarterly Review of Distance Education, 8(1), 47-57.

Xu, D., \& Smith Jaggars, S. (2011, March). Online and hybrid course enrollment and performance. CCRC Working Paper No. 31. 


\section{Biographies}

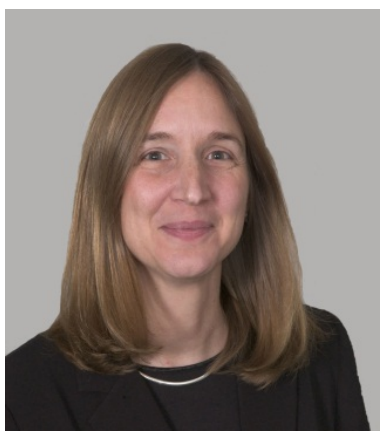

Meg Coffin Murray is a Professor of Information Systems who holds a joint appointment in the Coles College of Business and the University College at Kennesaw State University. She holds a Ph.D. in Information Systems and has over thirty years of experience in both academe and industry and has been the recipient of several National Science Foundation grants to enhance STEM education. Dr. Murray specializes in the development and implementation of emerging technologies to meet business and societal needs. Her current work devises strategies to assess, remediate and amplify skills needed to leverage IT in innovation, a primary driver of economic growth.

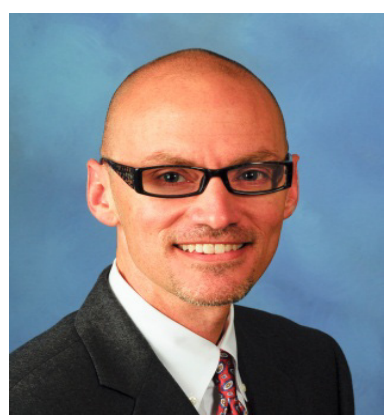

Jorge Pérez is a Professor of Information Systems at Kennesaw State University and a 2013-14 ACE Fellow. He holds a Ph.D. in information systems from Florida State University and has two decades of experience as a consultant, systems analyst, web developer and educator. Professor Pérez has published research on information security, diffusion of innovations, IS education and online learning. His current research on digital literacy centers on identifying, measuring and amplifying computing competencies.

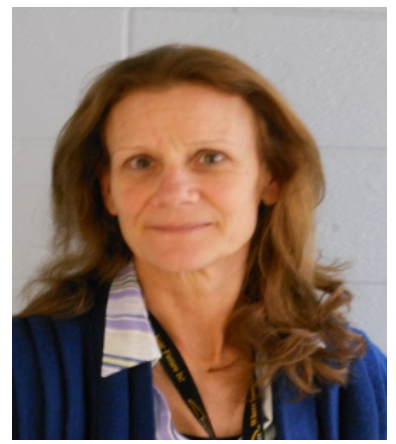

Debra Geist is a Lecturer of Information Systems at Kennesaw State University. With over thirty years in the field of Information Technology, she has collaborated with professionals from the private, public, government and academic sectors to accommodate technical needs and achieve competitive advantage through the application of information systems. Her background, combined with her first-hand experience of the evolution of technology, provide a wealth of knowledge to contribute to the pursuit of promoting digital literacy in the classroom and researching distance learning methodologies.

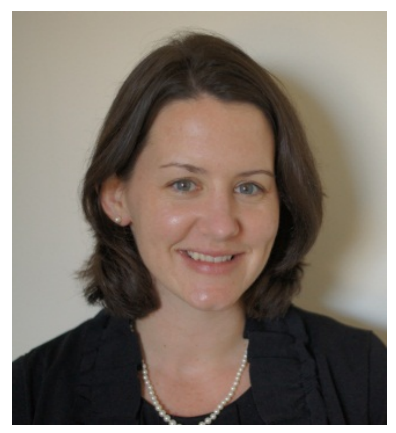

Alison Hedrick is a Lecturer of Information Systems in the Department of First-Year Programs at Kennesaw State University. She holds a M.S. in Information Systems, has six years of experience as an IT professional, and currently teaches hybrid and online sections of a digital literacy course. Her research interests encompass digital literacy and distance learning, specifically leveraging technology to better engage and retain online students. 